\title{
Souza, Vanderlei Sebastião de Em busca do Brasil: Edgard Roquette-Pinto e o retrato antropológico brasileiro (1905-1935)
}

\author{
Leonardo Dallacqua de Carvalho*
}

Rio de Janeiro: Ed. FGV; Fiocruz, 2017. 480p.

Publicado em 2017, Em busca do Brasil, de autoria de Vanderlei Sebastião de Souza, é fruto da tese de doutorado defendida na Casa de Oswaldo Cruz/ Fiocruz e agraciada com o III Prêmio de Teses da Anpuh, no biênio de 20112012. Os cinco capítulos que compõem o livro trazem à tona a preocupação com o tema da identidade nacional na trajetória política e científica do médico e antropólogo Edgard Roquette-Pinto. Em especial, a obra analisa a sua relação com a antropologia física, suas interlocuções transoceânicas e a ampla discussão racial mobilizada durante as primeiras décadas do século XX.

As perspectivas da história das ciências e da história intelectual contribuíram para fundamentar a afirmação de que as pesquisas de Roquette-Pinto possuíam caráter não apenas científico, mas politicamente comprometido com a questão da identidade nacional. Cartas pessoais, conferências, livros e artigos são sintomáticos para observar a articulação entre ciência e a viabilidade da composição racial brasileira, da qual o antropólogo buscava ressaltar suas principais características. Ou melhor, como delimita Souza, nas entrelinhas de sua produção há um aspecto militante em que "assumiu como sua missão intelectual e política o projeto de elaboração de um amplo retrato racial do país” (p.447).

Outro aspecto relevante da pesquisa diz respeito ao cuidado das fontes. Além de garimpar o Arquivo de Antropologia Física do Museu Nacional, houve a interlocução com o Arquivo Pessoal de Edgard Roquette-Pinto. A soma de um conjunto documental pouco explorado e a habilidade de organização das fontes

\footnotetext{
* Doutorando, Fundação Oswaldo Cruz (Fiocruz), Casa de Oswaldo Cruz (COC), Programa de PósGraduação em História das Ciências e da Saúde. Rio de Janeiro, RJ, Brasil. leo.historiafiocruz@gmail. com <http://orcid.org/0000-0002-7893-3092>
} 
pelo autor permitiram uma leitura mais detalhada da trajetória do antropólogo brasileiro, razão pela qual o livro torna-se também um modelo metodológico de tratamento da documentação de intelectuais. Aliás, o uso da palavra "retrato", no título do livro, oferece a dimensão das expectativas da autoria: um desenvolvimento aprofundado sobre a relação entre Roquette-Pinto e o Brasil.

A rigor, uma vez que a tônica da investigação é a identidade nacional, gostaria de estabelecer as principais contribuições entre raça, ciência, nação e eugenia. Isso porque não há como separar o projeto de nação de Roquette-Pinto e a discussão sobre as características hereditárias da população brasileira. A retórica biológica do amálgama racial, desde pelo menos a segunda metade do século XIX brasileiro, transitou na arena pública e política com relação aos efeitos da pluralidade racial para o desenvolvimento do país. Parte da intelectualidade indagava de que maneira a mistura de raças seria benéfica para os anseios de progresso nacional, especialmente porque as nações ditas adiantadas compunham/preteriam, ao menos fenotipicamente, uma massa homogênea de seus habitantes. As impressões de viajantes como Agassiz ou Gobineau sinalizavam um Brasil inviável sob o ponto de vista do melting pot.

O período também é caracterizado pelo fervor dos estudos que almejavam desvendar a hereditariedade das populações. Na Inglaterra de Darwin, seu primo Francis Galton formulava o conceito de eugenia, uma teoria científica que aspirava explicar os "talentos hereditários" e indicar fórmulas de aumentar o índice de dotação física e intelectual dos seres humanos. França e Itália, com Broca e Lombroso, respectivamente, pensavam por meio da antropometria e da psicologia características que distinguiam os sujeitos. A sedução de tais teses gerou adaptações para o contexto brasileiro.

Substancialmente, o capítulo 1 constitui um esforço de Vanderlei de Souza em resgatar as etapas iniciais da formação de Edgard Roquette-Pinto. Formado em medicina na Faculdade de Medicina que hoje pertence à Universidade Federal do Rio de Janeiro (UFRJ), iniciou sua carreira como antropólogo físico no Museu Nacional no ano de 1905, em meio à atmosfera da discussão sobre a "população ideal". Como destaca o autor, a viagem à Europa e as andanças pelo sertão brasileiro nos anos seguintes possibilitaram ao antropólogo um interesse nos estudos a respeito da formação racial do país. A descoberta do Brasil por Roquette-Pinto era também a sua própria descoberta enquanto intelectual brasileiro.

Os capítulos 2 e 3 representam o processo de encontro com a sua perspectiva teórica de brasilidade. A aproximação a grupos indígenas como os Parecis 
e Nambiquaras contribuiu para ampliar sua perspectiva etnográfica, negando as discussões desumanizantes que os individualizavam como "selvagens". Com efeito, conforme destaca o autor, cada vez mais o intelectual brasileiro buscava internacionalizar suas discussões científicas no campo da antropologia. Se anteriormente a antropologia física era iluminada por Broca, Topinard, Bertillon e outros, agora, uma nova geração aparece refletindo sob o prisma da escola alemã, assinalada por nomes como Rudolf Martin, Eugen Fischer e Félix von Luschan. Para o intelectual do Museu Nacional, a antropologia emerge como um empreendimento científico e político ao mesmo tempo.

O capítulo 4 ressalta a internacionalização nos estudos de Roquette-Pinto, visto que o debate sobre a miscigenação e a eugenia assume lugar privilegiado no livro de Souza. Um aspecto salta aos olhos: a polivalência do antropólogo na montagem de sua lógica da miscigenação racial. Isto é, Roquette-Pinto dialogou com Charles Davenport e Eugen Fischer, ao mesmo tempo que estabeleceu conexões com Rüdiger Bilden e Franz Boas. O que aparenta uma contradição teórica é na verdade, como explica Souza, a construção interpretativa de Roquette-Pinto, uma vez que realizou uma leitura seletiva desses autores, buscando apenas os argumentos que se adequavam às suas expectativas de valorização dos mestiços brasileiros. Por exemplo, pode-se indagar qual foi o malabarismo teórico desempenhado por Roquette-Pinto para dialogar com Fischer, um intelectual que assumia posições antissemitas e arianistas e brandia a hierarquização das raças pela perspectiva eugênica. A explicação, conforme argumenta Souza, estava na apropriação seletiva feita por Roquette-Pinto, pois teria desconsiderado a incômoda questão racial de Fischer, apropriando-se apenas dos fatores que mais se acomodassem aos seus pressupostos científicos.

Em termos políticos, essa leitura seletiva da antropologia alemã é apresentada no capítulo 5, nas discussões sobre imigração propostas por Roquette-Pinto. A defesa do processo de miscigenação praticado no Brasil, de acordo com Souza, foi um fator substancial da atuação do antropólogo como homem público. Do ponto de vista de Roquette-Pinto, o foco da seleção imigratória deveria excluir uma análise por grupos raciais e priorizar o indivíduo, afastando o determinismo racial das discussões sobre política imigratória. Na condição de nacionalista preocupado com o lugar do trabalhador brasileiro frente à imigração desenfreada, recusava a chave interpretativa da negação de imigrantes asiáticos, árabes, judeus ou eslavos por motivos raciais. $\mathrm{O}$ amparo do poder público ao elemento nacional não significaria a exclusão pela perspectiva racial dos imigrantes. 
Em busca do Brasil avança nas discussões sobre a questão racial no país por meio de um trabalho cuja habilidade com a história intelectual constitui um dos seus méritos. A inserção da obra no campo historiográfico da identidade nacional soma-se às leituras de Brasil a exemplo de Lucia Lippi Oliveira em A questão nacional na Primeira República (Oliveira, 1990), Nísia Trindade Lima em Um sertão chamado Brasil (Lima, 1999) e Regina Horta Duarte no livro A biologia militante (Duarte, 2010). Com estrutura de capítulos racional e preocupado com uma escrita simples, mas ao mesmo tempo artesanal, Souza entra na estante dos pesquisadores interessados em compreender as diversas faces identitárias do Brasil. A melhor definição talvez esteja com Ricardo Ventura Santos, pesquisador da Fundação Oswaldo Cruz e do Museu Nacional/UFRJ, quando menciona na orelha do livro: "Inquestionavelmente, este livro apresenta uma das principais e mais sofisticadas reflexões oriundas de um ciclo que, iniciado na década de 1990, e do qual participaram diversos pesquisadores, vem buscando compreender o locus da obra de Roquette-Pinto no cenário do pensamento social brasileiro entre o final do século XIX e o início do XX". Tal trabalho é o que academicamente definimos como o "estado da arte" sobre um tema.

\section{REFERÊNCIAS}

DUARTE, Regina Horta. A Biologia Militante: o Museu Nacional, especialização científica, divulgação do conhecimento e práticas políticas no Brasil, 1926-1945. Belo Horizonte: Ed. UFMG, 2010.

LIMA, Nísia Trindade. Um sertão chamado Brasil: intelectuais e representação geográfica da identidade nacional. Rio de Janeiro: Revan; Iuperj; Ucam, 1999.

OLIVEIRA, Lúcia Lippi. A questão nacional na Primeira República. São Paulo: Brasiliense; Brasília: CNPq, 1990.

Resenha recebida em 6 de fevereiro de 2018.

Aprovada em 20 de fevereiro de 2018.

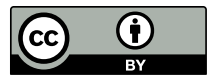

